\title{
Stem Cells: Current Status and Therapeutic Implications
}

\author{
Kaladhar B. Reddy ${ }^{1,2}$ \\ 1 Department of Pathology, Wayne State University, Detroit, MI 48201, USA; kreddy@med.wayne.edu \\ 2 Karmanos Cancer Institute, Wayne State University, Detroit, MI 48201, USA
}

Received: 21 September 2020; Accepted: 18 November 2020; Published: 20 November 2020

check for updates

\begin{abstract}
Cancer stem cells (CSCs) are a class of pluripotent cells that have been observed in most types of cancers. Evolving evidence suggests that CSCs, has the ability to self-renew and initiate tumors, may be responsible for promoting therapeutic resistance, tumor recurrence and metastasis. Tumor heterogeneity is originating from CSCs and its progenitors are recognized as major difficulty in efficaciously treating cancer patients. Therefore, understanding the biological mechanisms by which CSCs survive chemo- and-radiation therapy has the potential to identify new therapeutic strategies in the future. In this review, we summarized recent advances in CSC biology and their environment, and discuss about the potential therapies to prevent therapeutic resistance.
\end{abstract}

Keywords: cancer stem cells; stem cell niche; cancer

\section{Introduction}

Stem cells are a small number of pluripotent cells in tissue that can either mitotically divide to self-renew and produce more stem cells or differentiate into mature cells of a particular tissue. There are two types of stem cells-embryonic stem cells (ESC) and adult stem cells. ESC is obtained from a 3-5 day-old blastocyst, and is capable of giving rise to any type of organ in the body [1]. Adult stem cells are restricted to a specific tissue and have the ability to self-renewal and produce mature cells under highly controlled microenvironment [2]. Adult stem cells have two characteristic features. First, they can self-replicate for long periods of time. Second, they give can rise to mature cell types that have characteristic morphologies (shapes) and specialized functions. Normally, adult stem cells generate an intermediate cell called a precursor cell. Precursor cells are usually regarded as tissue-specific stem cells that are committed to differentiate along a particular cellular development pathway [3]. Until recently, it was believed that adult stem cells could create only similar types of cells. For instance, it was thought that stem cells residing in the bone marrow could give rise only to blood cells. However, new data suggests that adult stem cells are able to create unrelated types of cells. For instance, bone marrow stem cells may be able to create muscle cells or $\beta$ islet cells [4,5]. Their primary functions are to maintain the steady-state functioning of a cell—called homeostasis—and, with limitations, to replace cells that die because of injury or disease.

\section{Key Features of Normal and Cancer Stem Cells}

There is evidence to show both normal stem cells (NSCs) and cancer stem cells (CSCs) have many similarities, including migratory, self-renewal, slow cycling and differentiation properties [6]. Both NSCs and CSCs have the capacity for asymmetric division for self-renewal, which produces stem cells and progenitor cells, which play a major role in tissue repair or cancer. They both use similar signaling pathways (Wnt, Notch, Sonic Hedgehog, etc.) for self-renewal [7,8]. In both, life span is extended by telomeres and telomerase activity [9], and they can be identified based on cell-surface 
markers [10]. Both NSCs and CSCs escapes immune surveillance by reducing the expression of M1 macrophage inhibitors CD200 and CD44 blocking macrophage M2 polarization and phagocytic activity. In addition, tumor microenvironment (TME), like IL4, IL-6, IL-10, TGF- $\beta$, paralyzing the immune responses [11]. Some of the differences between NSCs and CSCs are: NSCs have extensive self-renewal capacity, highly regulated self-renewal and differentiation, normal karyotype, quiescent, and can generate normal progeny with limited proliferative potential. CSCs have indefinite self-renewal capacity, highly dysregulated self-renewal and differentiation, abnormal karyotype [12,13], mitotically less active than other cancer cells and have the capacity to produce phenotypically diverse progeny. CSCs are highly resistant to lack of oxygen compared to NSCs [14]. NSCs use oxidative phosphorylation (OXPHOS) as a primary source of energy, whereas glycolysis as a main source of energy $[15,16]$. One of the major differences between NSCs and CSCs is their degree of dependence on the stem cell niche. NSC is supported by niche to maintain homeostasis, whereas, CSCs play a major role in deregulation of the niche by promoting invasion and metastasis $[17,18]$ (Table 1$)$.

Table 1. Distinguishing Characteristics of Normal and Cancer stem cells.

\begin{tabular}{cc}
\hline Normal Stem Cells (NSCs) & Cancer Stem Cells (CSCs) \\
\hline Tightly regulated self-renewal capacity & Highly dysregulated self-renewal capacity \\
\hline Generates normal progeny & Phenotypically diverse progeny \\
\hline Normal Karyotype & Abnormal Karyotype \\
\hline Relatively long telomeres & Short telomeres \\
\hline Oxidative phosphorylation & Glycolysis \\
\hline Normal oxygen through blood vessels & Highly resistant to lack of oxygen \\
\hline Niche modifies local environment for immune & protection of NSCs.
\end{tabular}

\section{Identification of Cancer Stem Cells}

Proportion of CSCs is low compared to total mass of the tumor(s), cell-surface markers have proven useful for isolation and enriching CSCs from different cancers (Table 2). For the first time, it was shown $\mathrm{CD} 34^{+} \mathrm{CD} 38^{-}$stem cells initiated human myeloid leukemia after transplantation into SCID mice [19]. Breast cancer stem cells identified by CD $44^{+} \mathrm{CD} 24^{-}$cells formed tumors into Nod/Scid mice [20]. CD44 is a transmembrane glycoprotein on the surface of endothelial cells and leukocytes, which binds to extracellular matrix and activates EGFR and ErbB2 and enhances cell migration and differentiation [21,22]. CSC cell surface marker CD44 is used as a diagnostic marker for identification in breast, head and neck, prostate, lung, hepatocellular, pancreatic and squamous-cell carcinoma [23,24]. CD133 (Prominin-1) was originally described as a CSC marker for glioblastoma [25]. Moreover, glioblastoma tumors in vivo have shown that only the $\mathrm{CD}_{133^{+}}$cells had the ability to maintain tumorigenesis and generate heterogeneity [26]. In several cancers, including breast cancer, CD44 and CD24 cell surface markers have been used to isolate CSCs; however, they should not be regarded as universal markers. A number of studies have shown that CSCs were found in both the CD44 ${ }^{+}$ $\mathrm{CD}_{24}{ }^{-}$and $\mathrm{CD} 44^{+} \mathrm{CD} 24^{+}$fractions [27]. A similar story holds true for colorectal cancer in which the $\mathrm{EpCAM}^{\text {hi }} \mathrm{CD} 44^{+} \mathrm{CSC}$ subpopulation shared small overlap with CD133 [28]. However, in pancreatic cancer, where overlap between the $\mathrm{CD} 133^{+}$and $\mathrm{CD} 44^{+} \mathrm{CD} 24^{+}$populations varied significantly between specimens [29]. One of the reasons for limited overlap between the phenotypes of CSCs isolated from same tumor may be because of the presence of multiple CSC pools or variations arising from different isolation techniques. In addition, stringent assays to prove self-renewing activity was not applied in some cases. Identifying CSCs by using the expression of markers is the most popular method today, hence researchers are trying to identify specific markers for CSCs. 
Table 2. CSCs markers in different cancers.

\begin{tabular}{|c|c|}
\hline Type of Tumor & Cancer Stem Cell Markers \\
\hline Acute Myeloid Leukemia & $\mathrm{CD}^{2} 4^{+}, \mathrm{CD}_{3} 8^{+}$ \\
\hline Breast & $\mathrm{CD} 44^{+}, \mathrm{CD} 24^{-}, \mathrm{ALDH} 11^{\text {high }}, \mathrm{CD}_{133^{+}}$ \\
\hline Colorectal & $\mathrm{CD}_{133^{+}}, \mathrm{CD}_{4} 4^{+}, \mathrm{EpCAM}^{\text {high }}, \mathrm{ALDH} 1^{\text {high }}$ \\
\hline Glioblastoma & $\mathrm{CD}_{133^{+}}$ \\
\hline Head and neck & $\mathrm{CD}_{4} 4^{+}, \mathrm{CD} 24^{+,} \mathrm{ALDH}^{\text {high }}, \mathrm{CD} 271$ \\
\hline Liver & $\mathrm{CD}_{4} 4^{+}, \mathrm{CD} 0^{+}, \mathrm{CD} 133^{+}, \mathrm{ALDH} 1^{\text {high }}$ \\
\hline Lung & $\mathrm{CD}_{4} 4^{+}, \mathrm{CD} 0^{+}, \mathrm{CD}_{133^{+}}, \mathrm{ALDH}^{\text {high }}$ \\
\hline Ovarian & $\mathrm{CD}_{4} 4^{+}, \mathrm{CD} 117^{+}, \mathrm{CD} 133^{+}$ \\
\hline Skin & $\mathrm{CD} 20^{+}, \mathrm{CD} 271^{+}$ \\
\hline Melanoma & $\mathrm{CD} 133^{+}, \mathrm{ABCB}^{+}{ }^{+}, \mathrm{ALDH}_{1}{ }^{\text {high }}$ \\
\hline Pancreatic & $\mathrm{CD}_{4} 4^{+}, \mathrm{CD}_{2} 4^{+}, \mathrm{ESA}^{+}, \mathrm{CD}_{133^{+}}$ \\
\hline Prostate & $\mathrm{CD}_{133^{+}}, \mathrm{CD} 44^{+}, \mathrm{ALDH}^{\text {high }}$ \\
\hline
\end{tabular}

\section{Immunological Characteristics of Cancer Stem Cells}

CSCs have been shown to have immunosuppressive effects like stem cells [30,31]. Previous study of normal mesenchymal, haemopoietic stem cells was shown to interfere with $\mathrm{T}$ cell functions by impairing IFN- $\gamma$ production or by releasing large amounts of IL-10 [32,33]. Secretion of interleukins (IL), such as IL-4, IL-10, IL-13, and TGF- $\beta$ by CSCs was shown to have immunosuppressive effects on T cells, antigen-presenting cells, and natural killer (NK) cells [34]. In the aggressive melanoma cell line A375, it was shown that the immunogenic tumor-associated antigen, melanoma antigen recognized by T cells (MART-1) was expressed on differentiated melanoma cells, but not on malignant melanoma initiating cells (MMICs). Therefore, MART-1 specific T cells cannot eliminate MMICs [35]. Similarly, CD $44^{\text {high }} / \mathrm{CD} 24^{\text {low }}$ breast CSCs selectively escape from NK cell mediated killing and trastuzumab-dependent ADCC [36]. The expression of major histocompatibility complex I (MHC I) is often lower on the surface, and CSCs are more likely to be susceptible to NK cell-mediated cytotoxicity. However, in brain and breast cancers, CSCs often have a deficiency in NK-activating ligands, like NKG2D [37]. In addition, breast CSCs and glioblastoma stem cells secrete more TGF- $\beta$ as compared to normal tumor cells $[38,39]$. Colon CSCs secrete higher levels of interleukin 4 , which promotes drug resistance and inhibits anti-tumor immune responses [38,40]. This data suggests both NSCs and CSCs has the ability to regulate diverse membrane-bound and soluble factors, which enable these cells to modulate immune responses and protect them against immune-mediated destruction. The question whether or not CSCs are capable of seeding tumors depends on their ability to escape the immune system. However, most of the studies were done in mouse models lacking functional T, B, and NK cells, such as the NSG mice [41,42]. While studies are done in a completely immunodeficient animal model, however, for translational research, this model may not be ideal, as human subjects are immune-competent. The role of CSCs in tumor progression and tumor immune escape is best tested in models possessing a functional immune system.

\section{Cancer Stem Cell's Niche}

Niches are specialized microenvironments that regulate adult stem cells through cell-cell contacts and secreted factors. Normal niches are comprised of fibroblastic cells, endothelial and perivascular cells, extracellular matrix (ECM) components, immune cells, network of cytokines and growth factors [43]. Niches are a physical anchoring site for stem cells [17]. The niche maintains stem cells primarily in a quiescent state by providing signals that inhibit cell proliferation and growth as shown by stem cell's ability to retain bromodeoxyuridine labeling for a relatively long period of time in the 
hematopoietic, intestinal and hair follicle system [44-46]. The relationship between CSCs and ECM seems to be bidirectional in most cancers: the niche has the ability to alter the cellular fate of cancer cells, and conversely; CSCs can alter their microenvironment [47-49]. Previous studies have shown that CSCs and endothelial cells in the tumor microenvironment can transform normal fibroblasts into cancer-associated fibroblasts (CAFs) [50]. CAFs stimulate stemness via activation of Wnt and Notch pathways. Previous studies have shown that Wnt over expression and activation leads to leads to expression of stem cell markers in epithelial cells [51,52]. Mesenchymal stem cells are multipotent stromal cells that have been implicated in restoration of CSCs, as they secrete a variety of cytokines that have both autocrine and paracrine functions in the tumor milieu. Mesenchymal stem cells can promote cancer stemness through the NF-kB pathway by secreting CXCL12, interleukin-6(IL-6) and IL-8 [53]. To evade immune surveillance, the niche must immunosuppress the cytotoxic function and infiltration of natural killer cells (NKs) and CD8 ${ }^{+} \mathrm{T}$ cells. It was recently shown a sub-population of anti-tumor $\mathrm{CD}_{103^{+}}$dendritic cells, which can efficiently stimulate $\mathrm{CD} 8^{+} \mathrm{T}$ cells, is masked from tumor antigens by other tolerating antigen-presenting myeloid cell populations [54]. Tumor-associated macrophages secrete Transforming growth factor $\beta$ (TFG- $\beta$ ), which recruits T regulatory cells that also participate in immunosuppression [55]. Hypoxic CSCs impede CD8+T cell proliferation and activation and inhibit immunosurveillance [56]. Hypoxia promotes CSC survival through the ROS-induced TGF- $\beta$ pathway. Activation of TGF- $\beta$ as well as Wnt signaling pathways induces stemness by promoting an undifferentiated state in tumor cells $[57,58]$. In addition, normal stem cell niches, anchoring stem cells to the niche through cell-cell contacts, are critical for self-renewal. For example, Notch and Hedgehog signaling pathways require cell-cell contact. Notch ligands are mostly transmembrane proteins, particularly Jagged and Delta [59]. A bidirectional conversion between CSCs and non-CSCs can be triggered by an inflammatory stroma, which is characterized by elevated NF- $\mathrm{kB}$ signaling, enhancing Wnt activation, and inducing dedifferentiation of non-CSCs to CSCs [51]. Thus, the microenvironment seems to be crucial to maintain the properties of CSCs, preserve their phenotypic plasticity, and protect them from the immune system.

\section{Metastatic Cancer Stem Cells}

Metastatic cancer stem cells have the properties of cancer stem cells and ability to invade leading to metastasis. Both CSCs and cancer cells have the ability to metastasizes [60]. Genome sequencing studies suggest that primary tumors accumulate most of the mutations vital for metastasis, showing similarity between metastatic CSCs and primary CSCs [61,62]. In breast cancer, previous studies have shown CSCs identified by CD44 expression are involved in metastasis [54]. It was also shown that cancer cells expressing stem cell markers detected in the blood of breast cancer patients, when inoculated into immunodeficient mice, induced bone, liver, and lung metastasis [63]. In pancreatic cancer, only $\mathrm{CD} 133^{+} \mathrm{CXCR} 4^{+}$cells, but not $\mathrm{CD} 133^{+} \mathrm{CXCR}^{-}$cells, demonstrated metastatic activity, even though both subsets have tumor-promoting capacity [29]. In colorectal cancers, metastasis was mostly seen in CSCs that exhibited long-term self-renewing capacity [64]. Multiple circulating CSCs home to the bone marrow and spawn metastases, suggesting that metastatic CSCs enter the circulation. The metastatic CSC may have evolved from the primary tumor CSC or from a non-CSC within the tumor by changes induced by niches, EMT changes, etc. [65]. Interestingly, dormancy plays a major role tumor recurrence and metastatic spread after long lag periods in many cancers, including breast, melanoma and leukemia [66-68]. Since dormant cells are proliferatively quiescent, they survive chemotherapy, radiation therapy better than proliferating cells and the surviving cells eventually regrowth. It is possible that restricted supplies of nutrients and oxygen due to poor vascularization cause growth arrest and dormancy. Circulating metastatic cells co-express EMT and stem cell markers [69]. Even though EMT enables migration, it interferes with proliferation and metastatic growth [70]. Thus, metastatic cells that have undergone EMT may need to reacquire an epithelial phenotype by mesenchymal-to-epithelial transition (MET) to seed and resume growth at a metastatic site [71]. Little is known about entering and exiting dormancy at present, so better models are 
needed to understand dormancy. Some studies have shown multiple CSC pools exist within individual tumors in ovarian, breast, and squamous-cell carcinomas. In these tumors, distinct CSC populations regenerate the phenotypic and functional heterogeneity of the parental tumor (Figure 1) [27,72,73]. In primary colorectal cancers, three different types of tumor-initiating cells were identified from single patient's tumor. These tumor-initiating cells CSCs maintained tumor growth on serial transplantation, CSCs that are dormant or has partial self-renewal capacity, are activated in secondary or tertiary transplantation assays [64]. Tumor-initiating cells from PTEN-deficient glioblastoma, showed clonal heterogeneity, in which a series of phenotypically distinct self-renewing cells was observed in both the $\mathrm{CD}_{133^{+}}$and $\mathrm{CD} 133^{-}$fractions [74]. In skin squamous cell carcinoma, two CSC subsets located along the tumor-stromal interface displayed different growth kinetics and could interchange phenotypes [72]. The delineation of functionally distinct pools of CSCs requires cell-tracing studies in vivo in the future.

A. Single CSC

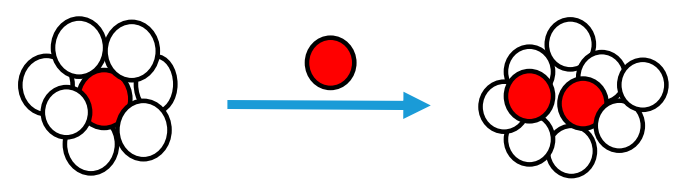

B. Multiple CSC
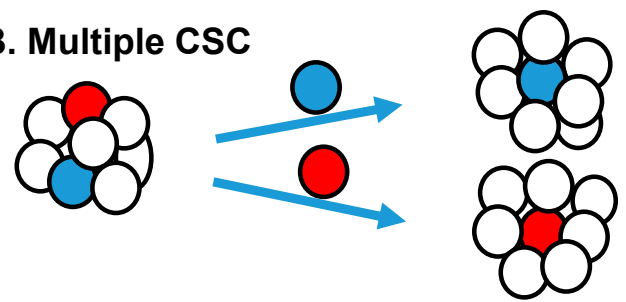

C. Phenotypic reversibility

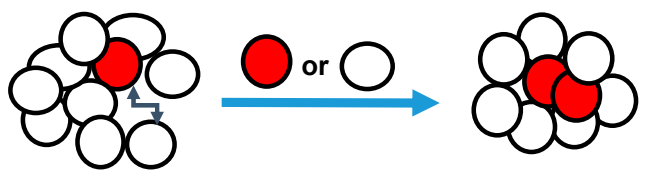

Figure 1. Schematic Models of Tumor Heterogeneity: (A) Single CSC pool may be present within the tumor. (B) Multiple distinct CSC pools with in individual tumors. (C) The CSC can be unstable, resulting in phenotypic reversion of cell-surface markers and CSC phenotype.

\section{Targeting Cancer Stem Cell}

Generally, CSCs appear to be resistant to conventional cancer therapies such as chemotherapy and radiation [42,75]. There is pre-clinical and clinical evidence to show CSCs are resistant to chemotherapy in a number of solid tumors, including breast [42,76]. A number of different strategies are explored to target CSCs, including self-renewal pathways, quiescence, CSC-specific cell surface molecules, stem cell niche, etc. There are many therapeutic agents against CSCs and are actively being evaluated in pre-clinical and clinical settings of various cancers [77]. Differentiation therapies that specifically targeted CSCs by exploiting their ability to differentiate can be effective is some cases. This strategy is successful in inducing cell-cycle progression in acute myeloid leukemia stem cells by G-CSF to promote sensitivity to chemotherapy [68]. Similarly, mouse glioblastoma stem cells when treated with BMP4 protein differentiates into Gila, resulting in reduced tumor growth, and tumor initiation capacity of CSCs upon transplantation [78,79]. Tumor cell plasticity present is a challenge to develop CSC targeted cancer therapies; a therapeutic eradication of CSCs might be followed by their regeneration from non-CSCs within the tumor under treatment [80]. Targeted therapies against Wnt, Notch and Hh pathways that frequently are deregulated in CSCs resulted in marked reduction in tumorigenic potential [42,81-85]. It was shown that high expression of $\mathrm{Hg}$ ligands in stromal plays a major role in the maintenance of CSCs and their niche. Notch pathway inhibition by a neutralizing antibody 
against the DLL4 ligand was effective in reducing CSC numbers in diverse solid xenograft tumors [86], whereas inhibition of Notch-4 expression within the CSC largely ablated breast tumor growth [87]. Tumor microenvironment supports CSCs, thus targeting CSC niche factors that regulate plasticity was shown to be effective in some tumors. Antibodies that abrogate the activation of c-Met by HGF significantly inhibited xenograft growth of colon tumors [86]. Antibodies against the fibronectin receptor $\alpha 4 \beta 1$ integrin reduced association of tumor cells with metastatic niches [88]. Targeting hypoxia through HIF- $1 \alpha$ and HIF- $2 \alpha$, which promote cell cycle via Myc, was a promising therapy for glioma patients $[89,90]$. The biological activities of CSCs are regulated by several pluripotent transcription factors, such as OCT4, Sox2, Nanog, KLF4, and MYC [91] and these factors have become targets for cancer treatment [10]. Other therapeutic targets currently being pursued are MicroRNA Mir 34a that was shown to suppress breast and prostate cancer CSCs and metastasis [92,93]. MicroRNA 199a was shown to target CD44 to suppress the tumorigenicity and multidrug resistance of ovarian cancer-initiating cells CD44 ${ }^{+} / \mathrm{CD} 117^{+}$[94]. In another study, miR145 was shown to inhibit CSCs by targeting Oct 4 and Sox2 in GBM-CD $133^{+}$and facilitated their differentiation into CD133 ${ }^{-}$non-CSCs [83].

\section{Conclusions and Future Directions}

An evolving consensus in the field is that under normal circumstances, normal stem cells (NSCs) maintain a homeostasis and replenish the adult cells while deregulation of NSCs can give rise to CSCs eventually leading to cancer and metastasis. The most studies show anti-CSC therapies to date could reduce rather than eradicated solid tumors in preclinical models. In standard clinical trials, tumor response criteria depend on measurements of tumor size, which largely reflects tumor responses to chemo- or radiation therapy in the non-CSC bulk tumor. Specific response criteria that provide a readout to anti-CSC agents in pre-clinical and clinical trials need to be standardized. An effective cancer therapy can be achieved by targeting the CSCs and bulk of tumor and creating a harsh microenvironment for the tumor cells to grow and metastasize.

Funding: This work was supported by Department of Pathology and WSU Boost Grant (to K.B.R.).

Conflicts of Interest: The author declares that they have no competing interests.

\section{References}

1. Rodgerson, D.O.; Harris, A. A Comparison of Stem Cells for Therapeutic Use. Stem Cell Rev. Rep. 2011, 7, 782-796. [CrossRef] [PubMed]

2. Morrison, S.J.; Kimble, J. Asymmetric and symmetric stem-cell divisions in development and cancer. Nature 2006, 441, 1068-1074. [CrossRef]

3. Robey, P.G. Series Introduction: Stem cells near the century mark. J. Clin. Investig. 2000, 105, 1489-1491. [CrossRef] [PubMed]

4. Gabr, M.M.; Zakaria, M.M.; Refaie, A.F.; Ismail, A.M.; Abou-El-Mahasen, M.A.; Ashamallah, S.A.; Khater, S.M.; El-Halawani, S.M.; Ibrahim, R.Y.; Uin, G.S.; et al. Insulin-Producing Cells from Adult Human Bone Marrow Mesenchymal Stem Cells Control Streptozotocin-Induced Diabetes in Nude Mice. Cell Transplant. 2013, 22, 133-145. [CrossRef] [PubMed]

5. Meligy, F.Y.; Shigemura, K.; Behnsawy, H.M.; Fujisawa, M.; Kawabata, M.; Shirakawa, T. The efficiency of in vitro isolation and myogenic differentiation of MSCs derived from adipose connective tissue, bone marrow, and skeletal muscle tissue. In Vitro Cell. Dev. Biol. Anim. 2012, 48, 203-215. [CrossRef] [PubMed]

6. Martín-Belmonte, F.; Perez-Moreno, M. Epithelial cell polarity, stem cells and cancer. Nat. Rev. Cancer 2011, 12, 23-38. [CrossRef]

7. Reya, T.; Clevers, H. Wnt signalling in stem cells and cancer. Nature 2005, 434, 843-850. [CrossRef]

8. Taipale, J.; Beachy, P.A. The Hedgehog and Wnt signalling pathways in cancer. Nature 2001, 411, 349-354. [CrossRef]

9. Robinson, N.; Taylor, D.J.; Schiemann, W.P. Stem cells, immortality, and the evolution of metastatic properties in breast cancer: Telomere maintenance mechanisms and metastatic evolution. J. Cancer Metastasis Treat. 2019, 5, 5. [CrossRef] 
10. Yang, L.; Shi, P.; Zhao, G.; Xu, J.; Peng, W.; Zhang, J.; Zhang, G.; Wang, X.; Dong, Z.; Chen, F.; et al. Targeting cancer stem cell pathways for cancer therapy. Signal Transduct. Target. Ther. 2020, 5, 1-35. [CrossRef]

11. Naik, S.; Larsen, S.B.; Cowley, C.J.; Fuchs, E. Two to Tango: Dialog between Immunity and Stem Cells in Health and Disease. Cell 2018, 175, 908-920. [CrossRef] [PubMed]

12. Rebuzzini, P.; Zuccotti, M.; Redi, C.A.; Garagna, S. Chromosomal Abnormalities in Embryonic and Somatic Stem Cells. Cytogenet. Genome Res. 2015, 147, 1-9. [CrossRef] [PubMed]

13. Thompson, S.L.; Compton, D.A. Chromosomes and cancer cells. Chromosome Res. 2011, 19, $433-444$. [CrossRef] [PubMed]

14. Hubert, C.G.; Rivera, M.; Spangler, L.C.; Wu, Q.; Mack, S.C.; Prager, B.C.; Couce, M.; McLendon, R.E.; Sloan, A.E.; Rich, J.N. A Three-Dimensional Organoid Culture System Derived from Human Glioblastomas Recapitulates the Hypoxic Gradients and Cancer Stem Cell Heterogeneity of Tumors Found In Vivo. Cancer Res. 2016, 76, 2465-2477. [CrossRef]

15. Chae, Y.C. Cancer stem cell metabolism: Target for cancer therapy. BMB Rep. 2018, 51, 319-326. [CrossRef]

16. Yadav, U.P.; Singh, T.; Kumar, P.; Sharma, P.; Kaur, H.; Sharma, S.; Singh, S.; Kumar, S.; Mehta, K. Metabolic Adaptations in Cancer Stem Cells. Front. Oncol. 2020, 10, 1010. [CrossRef]

17. Li, L.; Neaves, W.B. Normal Stem Cells and Cancer Stem Cells: The Niche Matters: Figure 1. Cancer Res. 2006, 66, 4553-4557. [CrossRef]

18. Pastò, A.; Consonni, F.M.; Sica, A. Influence of Innate Immunity on Cancer Cell Stemness. Int. J. Mol. Sci. 2020, 21, 3352. [CrossRef]

19. Lapidot, T.; Sirard, C.; Vormoor, J.; Murdoch, B.; Hoang, T.; Caceres-Cortes, J.; Minden, M.; Paterson, B.; Caligiuri, M.A.; Dick, J.E. A cell initiating human acute myeloid leukaemia after transplantation into SCID mice. Nature 1994, 367, 645-648. [CrossRef]

20. Al-Hajj, M.; Wicha, M.S.; Benito-Hernandez, A.; Morrison, S.J.; Clarke, M.F. Prospective identification of tumorigenic breast cancer cells. Proc. Natl. Acad. Sci. USA 2003, 100, 3983-3988. [CrossRef]

21. Misra, S.; Toole, B.P.; Ghatak, S. Hyaluronan Constitutively Regulates Activation of Multiple Receptor Tyrosine Kinases in Epithelial and Carcinoma Cells. J. Biol. Chem. 2006, 281, 34936-34941. [CrossRef] [PubMed]

22. Vermeulen, L.; Melo, F.D.S.E.; Van Der Heijden, M.; Cameron, K.A.; De Jong, J.H.; Borovski, T.; Tuynman, J.B.; Todaro, M.; Merz, C.; Rodermond, H.M.; et al. Wnt activity defines colon cancer stem cells and is regulated by the microenvironment. Nat. Cell Biol. 2010, 12, 468-476. [CrossRef] [PubMed]

23. Li, C.; Heidt, D.G.; Dalerba, P.; Burant, C.F.; Zhang, L.; Adsay, V.; Wicha, M.S.; Clarke, M.F.; Simeone, D.M. Identification of Pancreatic Cancer Stem Cells. Cancer Res. 2007, 67, 1030-1037. [CrossRef] [PubMed]

24. Prince, M.E.; Sivanandan, R.; Kaczorowski, A.; Wolf, G.T.; Kaplan, M.J.; Dalerba, P.; Weissman, I.L.; Clarke, M.F.; Ailles, L.E. Identification of a subpopulation of cells with cancer stem cell properties in head and neck squamous cell carcinoma. Proc. Natl. Acad. Sci. USA 2007, 104, 973-978. [CrossRef]

25. Singh, S.K.; Hawkins, C.; Clarke, I.D.; Squire, J.A.; Bayani, J.; Hide, T.; Henkelman, R.M.; Cusimano, M.D.; Dirks, P.B. Identification of human brain tumour initiating cells. Nature 2004, 432, 396-401. [CrossRef]

26. Lathia, J.D.; Gallagher, J.; Myers, J.T.; Li, M.; Vasanji, A.; McLendon, R.E.; Hjelmeland, A.B.; Huang, A.Y.; Rich, J.N. Direct In Vivo Evidence for Tumor Propagation by Glioblastoma Cancer Stem Cells. PLoS ONE 2011, 6, e24807. [CrossRef]

27. Meyer, M.J.; Fleming, J.M.; Lin, A.F.; Hussnain, S.A.; Ginsburg, E.; Vonderhaar, B.K. CD44posCD49fhiCD133/2hi Defines Xenograft-Initiating Cells in Estrogen Receptor-Negative Breast Cancer. Cancer Res. 2010, 70, 4624-4633. [CrossRef]

28. Dalerba, P.; Dylla, S.J.; Park, I.-K.; Liu, R.; Wang, X.; Cho, R.W.; Hoey, T.; Gurney, A.; Huang, E.H.; Simeone, D.M.; et al. Phenotypic characterization of human colorectal cancer stem cells. Proc. Natl. Acad. Sci. USA 2007, 104, 10158-10163. [CrossRef]

29. Hermann, P.C.; Huber, S.L.; Herrler, T.; Aicher, A.; Ellwart, J.W.; Guba, M.; Bruns, C.J.; Heeschen, C. Distinct Populations of Cancer Stem Cells Determine Tumor Growth and Metastatic Activity in Human Pancreatic Cancer. Cell Stem Cell 2007, 1, 313-323. [CrossRef]

30. Codd, A.S.; Kanaseki, T.; Torigo, T.; Tabi, Z. Cancer stem cells as targets for immunotherapy. Immunology 2017, 153, 304-314. [CrossRef]

31. Bruttel, V.S.; Wischhusen, J.; Wischhusen, J. Cancer Stem Cell Immunology: Key to Understanding Tumorigenesis and Tumor Immune Escape? Front. Immunol. 2014, 5, 360. [CrossRef] [PubMed] 
32. Beyth, S.; Borovsky, Z.; Mevorach, D.; Liebergall, M.; Gazit, Z.; Aslan, H.; Galun, E.; Rachmilewitz, J. Human mesenchymal stem cells alter antigen-presenting cell maturation and induce T-cell unresponsiveness. Blood 2005, 105, 2214-2219. [CrossRef] [PubMed]

33. Glennie, S.; Soeiro, I.; Dyson, P.J.; Lam, E.W.-F.; Dazzi, F.; Lutsiak, M.E.C.; Semnani, R.T.; De Pascalis, R.; Kashmiri, S.V.S.; Schlom, J.; et al. Bone marrow mesenchymal stem cells induce division arrest anergy of activated T cells. Blood 2005, 105, 2821-2827. [CrossRef] [PubMed]

34. Di Tomaso, T.; Mazzoleni, S.; Wang, E.; Sovena, G.; Clavenna, D.; Franzin, A.; Mortini, P.; Ferrone, S.; Doglioni, C.; Marincola, F.M.; et al. Immunobiological Characterization of Cancer Stem Cells Isolated from Glioblastoma Patients. Clin. Cancer Res. 2010, 16, 800-813. [CrossRef]

35. Schatton, T.; Frank, M.H. Antitumor Immunity and Cancer Stem Cells. Ann. N. Y. Acad. Sci. 2009, 1176, 154-169. [CrossRef]

36. Reim, F.; Dombrowski, Y.; Ritter, C.; Buttmann, M.; Häusler, S.; Ossadnik, M.; Krockenberger, M.; Beier, D.; Beier, C.P.; Dietl, J.; et al. Immunoselection of Breast and Ovarian Cancer Cells with Trastuzumab and Natural Killer Cells: Selective Escape of CD44high/CD24low/HER2low Breast Cancer Stem Cells. Cancer Res. 2009, 69, 8058-8066. [CrossRef]

37. Wang, B.; Wang, Q.; Wang, Z.; Jiang, J.; Yu, S.-C.; Ping, Y.-F.; Yang, J.; Xu, S.-L.; Ye, X.-Z.; Xu, C.; et al. Metastatic Consequences of Immune Escape from NK Cell Cytotoxicity by Human Breast Cancer Stem Cells. Cancer Res. 2014, 74, 5746-5757. [CrossRef]

38. Lottaz, C.; Beier, D.; Meyer, K.; Kumar, P.; Hermann, A.; Schwarz, J.; Junker, M.; Oefner, P.J.; Bogdahn, U.; Wischhusen, J.; et al. Transcriptional Profiles of CD133+ and CD133- Glioblastoma-Derived Cancer Stem Cell Lines Suggest Different Cells of Origin. Cancer Res. 2010, 70, 2030-2040. [CrossRef]

39. Shipitsin, M.; Campbell, L.L.; Argani, P.; Weremowicz, S.; Bloushtain-Qimron, N.; Yao, J.; Nikolskaya, T.; Serebryiskaya, T.; Beroukhim, R.; Hu, M.; et al. Molecular Definition of Breast Tumor Heterogeneity. Cancer Cell 2007, 11, 259-273. [CrossRef]

40. Todaro, M.; Alea, M.P.; Di Stefano, A.B.; Cammareri, P.; Vermeulen, L.; Iovino, F.; Tripodo, C.; Russo, A.; Gulotta, G.; Medema, J.P.; et al. Colon Cancer Stem Cells Dictate Tumor Growth and Resist Cell Death by Production of Interleukin-4. Cell Stem Cell 2007, 1, 389-402. [CrossRef]

41. Shultz, L.D.; Lyons, B.L.; Burzenski, L.M.; Gott, B.; Chen, X.; Chaleff, S.; Kotb, M.; Gillies, S.D.; King, M.; Mangada, J.; et al. Human Lymphoid and Myeloid Cell Development in NOD/LtSz-scid IL2R $\gamma$ nullMice Engrafted with Mobilized Human Hemopoietic Stem Cells. J. Immunol. 2005, 174, 6477-6489. [CrossRef] [PubMed]

42. Yin, S.; Xu, L.; Bonfil, R.D.; Banerjee, S.; Sarkar, F.H.; Sethi, S.; Reddy, K.B. Tumor-Initiating Cells and FZD8 Play a Major Role in Drug Resistance in Triple-Negative Breast Cancer. Mol. Cancer Ther. 2013, 12, 491-498. [CrossRef] [PubMed]

43. Korkaya, H.; Liu, S.; Wicha, M.S. Breast cancer stem cells, cytokine networks, and the tumor microenvironment. J. Clin. Investig. 2011, 121, 3804-3809. [CrossRef] [PubMed]

44. Arai, F.; Hirao, A.; Ohmura, M.; Sato, H.; Matsuoka, S.; Takubo, K.; Ito, K.; Koh, G.Y.; Suda, T. Tie2/Angiopoietin-1 Signaling Regulates Hematopoietic Stem Cell Quiescence in the Bone Marrow Niche. Cell 2004, 118, 149-161. [CrossRef]

45. Tumbar, T.; Guasch, G.; Greco, V.; Blanpain, C.; Lowry, W.E.; Rendl, M.; Fuchs, E. Defining the Epithelial Stem Cell Niche in Skin. Science 2004, 303, 359-363. [CrossRef]

46. Zhang, J.; Niu, C.; Ye, L.; Huang, H.; He, X.; Tong, W.-G.; Ross, J.; Haug, J.S.; Johnson, T.; Feng, J.Q.; et al. Identification of the haematopoietic stem cell niche and control of the niche size. Nature 2003, 425, 836-841. [CrossRef]

47. Heddleston, J.M.; Li, Z.; McLendon, R.E.; Hjelmeland, A.B.; Rich, J.N. The hypoxic microenvironment maintains glioblastoma stem cells and promotes reprogramming towards a cancer stem cell phenotype. Cell Cycle 2009, 8, 3274-3284. [CrossRef]

48. Ricci-Vitiani, L.; Pallini, R.; Biffoni, M.; Todaro, M.; Invernici, G.; Cenci, T.; Maira, G.; Parati, E.A.; Stassi, G.; LaRocca, L.M.; et al. Tumour vascularization via endothelial differentiation of glioblastoma stem-like cells. Nature 2010, 468, 824-828. [CrossRef]

49. Wang, R.; Chadalavada, K.; Wilshire, J.; Kowalik, U.; Hovinga, K.E.; Geber, A.; Fligelman, B.; Leversha, M.; Brennan, C.; Tabar, V. Glioblastoma stem-like cells give rise to tumour endothelium. Nature 2010, 468, 829-833. [CrossRef] 
50. Kalluri, R.; Zeisberg, M. Fibroblasts in cancer. Nat. Rev. Cancer 2006, 6, 392-401. [CrossRef]

51. Schwitalla, S.; Fingerle, A.A.; Cammareri, P.; Nebelsiek, T.; Göktuna, S.I.; Ziegler, P.K.; Canli, O.; Heijmans, J.; Huels, D.J.; Moreaux, G.; et al. Intestinal Tumorigenesis Initiated by Dedifferentiation and Acquisition of Stem-Cell-like Properties. Cell 2013, 152, 25-38. [CrossRef] [PubMed]

52. Visvader, J.E.; Lindeman, G.J. Cancer stem cells in solid tumours: Accumulating evidence and unresolved questions. Nat. Rev. Cancer 2008, 8, 755-768. [CrossRef] [PubMed]

53. Cabarcas, S.M.; Mathews, L.A.; Farrar, W.L. The cancer stem cell niche-there goes the neighborhood? Int. J. Cancer 2011, 129, 2315-2327. [CrossRef] [PubMed]

54. Broz, M.L.; Binnewies, M.; Boldajipour, B.; Nelson, A.E.; Pollack, J.L.; Erle, D.J.; Barczak, A.; Rosenblum, M.D.; Daud, A.; Barber, D.L.; et al. Dissecting the Tumor Myeloid Compartment Reveals Rare Activating Antigen-Presenting Cells Critical for T Cell Immunity. Cancer Cell 2014, 26, 638-652. [CrossRef]

55. Chanmee, T.; Ontong, P.; Konno, K.; Itano, N.; Chanmee, T. Tumor-Associated Macrophages as Major Players in the Tumor Microenvironment. Cancers 2014, 6, 1670-1690. [CrossRef]

56. Wei, J.; Wu, A.; Kong, L.-Y.; Wang, Y.; Fuller, G.; Fokt, I.; Melillo, G.; Priebe, W.; Heimberger, A.B. Hypoxia Potentiates Glioma-Mediated Immunosuppression. PLoS ONE 2011, 6, e16195. [CrossRef]

57. Pavlides, S.; Tsirigos, A.; Vera, I.; Flomenberg, N.; Frank, P.G.; Casimiro, M.C.; Wang, C.; Pestell, R.G.; Martinez-Outschoorn, U.E.; Howell, A.; et al. Transcriptional evidence for the "Reverse Warburg Effect" in human breast cancer tumor stroma and metastasis: Similarities with oxidative stress, inflammation, Alzheimer's disease, and "Neuron-Glia Metabolic Coupling”. Aging 2010, 2, 185-199. [CrossRef]

58. Scheel, C.; Eaton, E.N.; Li, S.H.-J.; Chaffer, C.L.; Reinhardt, F.; Kah, K.-J.; Bell, G.W.; Guo, W.; Rubin, J.S.; Richardson, A.L.; et al. Paracrine and Autocrine Signals Induce and Maintain Mesenchymal and Stem Cell States in the Breast. Cell 2011, 145, 926-940. [CrossRef]

59. Gilbertson, R.J.; Rich, J.N. Making a tumour's bed: Glioblastoma stem cells and the vascular niche. Nat. Rev. Cancer 2007, 7, 733-736. [CrossRef]

60. Fares, J.; Fares, M.Y.; Khachfe, H.H.; Salhab, H.A.; Fares, Y. Molecular principles of metastasis: A hallmark of cancer revisited. Signal Transduct. Target. Ther. 2020, 5, 1-17. [CrossRef]

61. Elbaiomy, M.A.; Akl, T.; Atwan, N.; Elsayed, A.A.; Elzaafarany, M.; Shamaa, S. Clinical Impact of Breast Cancer Stem Cells in Metastatic Breast Cancer Patients. J. Oncol. 2020, 2020, 1-8. [CrossRef]

62. Yachida, S.; Jones, S.; Bozic, I.; Antal, T.; Leary, R.J.; Fu, B.; Kamiyama, M.; Hruban, R.H.; Eshleman, J.R.; Nowak, M.A.; et al. Distant metastasis occurs late during the genetic evolution of pancreatic cancer. Nature 2010, 467, 1114-1117. [CrossRef]

63. Baccelli, I.; Schneeweiss, A.; Riethdorf, S.; Stenzinger, A.; Schillert, A.; Vogel, V.; Klein, C.; Saini, M.; Bäuerle, T.; Wallwiener, M.; et al. Identification of a population of blood circulating tumor cells from breast cancer patients that initiates metastasis in a xenograft assay. Nat. Biotechnol. 2013, 31, 539-544. [CrossRef] [PubMed]

64. Dieter, S.M.; Ball, C.R.; Hoffmann, C.M.; Nowrouzi, A.; Herbst, F.; Zavidij, O.; Abel, U.; Arens, A.; Weichert, W.; Brand, K.; et al. Distinct Types of Tumor-Initiating Cells Form Human Colon Cancer Tumors and Metastases. Cell Stem Cell 2011, 9, 357-365. [CrossRef] [PubMed]

65. Zhou, J.; Zhu, X.; Wu, S.; Guo, J.; Zhang, K.; Xu, C.; Chen, H.; Jin, Y.; Sun, Y.; Zheng, S.; et al. Epithelial-mesenchymal transition status of circulating tumor cells in breast cancer and its clinical relevance. Cancer Biol. Med. 2020, 17, 169-180. [PubMed]

66. Pece, S.; Tosoni, D.; Confalonieri, S.; Mazzarol, G.; Vecchi, M.; Ronzoni, S.; Bernard, L.; Viale, G.; Pelicci, P.G.; Di Fiore, P.P. Biological and Molecular Heterogeneity of Breast Cancers Correlates with Their Cancer Stem Cell Content. Cell 2010, 140, 62-73. [CrossRef]

67. Roesch, A.; Fukunaga-Kalabis, M.; Schmidt, E.C.; Zabierowski, S.E.; Brafford, P.A.; Vultur, A.; Basu, D.; Gimotty, P.; Vogt, T.; Herlyn, M. A Temporarily Distinct Subpopulation of Slow-Cycling Melanoma Cells Is Required for Continuous Tumor Growth. Cell 2010, 141, 583-594. [CrossRef]

68. Saito, Y.; Uchida, N.; Tanaka, S.; Suzuki, N.; Tomizawa-Murasawa, M.; Sone, A.; Najima, Y.; Takagi, S.; Aoki, Y.; Wake, A.; et al. Induction of cell cycle entry eliminates human leukemia stem cells in a mouse model of AML. Nat. Biotechnol. 2010, 28, 275-280. [CrossRef]

69. Plaks, V.; Koopman, C.D.; Werb, Z. Circulating Tumor Cells. Science 2013, 341, 1186-1188. [CrossRef]

70. Ocaña, O.H.; Córcoles, R.; Fabra, Á.; Moreno-Bueno, G.; Acloque, H.; Vega, S.; Barrallo-Gimeno, A.; Cano, A.; Nieto, M.A. Metastatic Colonization Requires the Repression of the Epithelial-Mesenchymal Transition Inducer Prrx1. Cancer Cell 2012, 22, 709-724. [CrossRef] 
71. Steinbichler, T.B.; Savic, D.; Dudás, J.; Kvitsaridze, I.; Skvortsov, S.; Riechelmann, H.; Skvortsova, I.-I. Cancer stem cells and their unique role in metastatic spread. Semin. Cancer Biol. 2020, 60, 148-156. [CrossRef] [PubMed]

72. Schober, M.; Fuchs, E. Tumor-initiating stem cells of squamous cell carcinomas and their control by TGFand integrin/focal adhesion kinase (FAK) signaling. Proc. Natl. Acad. Sci. USA 2011, 108, 10544-10549. [CrossRef] [PubMed]

73. Stewart, J.M.; Shaw, P.A.; Gedye, C.; Bernardini, M.Q.; Neel, B.G.; Ailles, L.E. Phenotypic heterogeneity and instability of human ovarian tumor-initiating cells. Proc. Natl. Acad. Sci. USA 2011, 108, 6468-6473. [CrossRef] [PubMed]

74. Chen, R.; Nishimura, M.C.; Bumbaca, S.M.; Kharbanda, S.; Forrest, W.F.; Kasman, I.M.; Greve, J.M.; Soriano, R.H.; Gilmour, L.L.; Rivers, C.S.; et al. A Hierarchy of Self-Renewing Tumor-Initiating Cell Types in Glioblastoma. Cancer Cell 2010, 17, 362-375. [CrossRef] [PubMed]

75. Bao, S.; Wu, Q.; McLendon, R.E.; Hao, Y.; Shi, Q.; Hjelmeland, A.B.; Dewhirst, M.W.; Bigner, D.D.; Rich, J.N. Glioma stem cells promote radioresistance by preferential activation of the DNA damage response. Nature 2006, 444, 756-760. [CrossRef]

76. Li, X.; Lewis, M.T.; Huang, J.; Gutierrez, C.; Osborne, C.K.; Wu, M.-F.; Hilsenbeck, S.G.; Pavlick, A.; Zhang, X.; Chamness, G.C.; et al. Intrinsic Resistance of Tumorigenic Breast Cancer Cells to Chemotherapy. J. Natl. Cancer Inst. 2008, 100, 672-679. [CrossRef]

77. Vidal, S.J.; Rodriguezbravo, V.; Galsky, M.D.; Cordon-Cardo, C.; Domingo-Domenech, J. Targeting cancer stem cells to suppress acquired chemotherapy resistance. Oncogene 2014, 33, 4451-4463. [CrossRef]

78. Lombardo, Y.; Scopelliti, A.; Cammareri, P.; Todaro, M.; Iovino, F.; Ricci-Vitiani, L.; Gulotta, G.; Dieli, F.; De Maria, R.; Stassi, G. Bone Morphogenetic Protein 4 Induces Differentiation of Colorectal Cancer Stem Cells and Increases Their Response to Chemotherapy in Mice. Gastroenterology 2011, 140, 297-309.e6. [CrossRef]

79. Piccirillo, S.G.M.; Reynolds, B.A.; Zanetti, N.; Lamorte, G.; Binda, E.; Broggi, G.; Brem, H.; Olivi, A.; DiMeco, F.; Vescovi, A.L. Bone morphogenetic proteins inhibit the tumorigenic potential of human brain tumour-initiating cells. Nature 2006, 444, 761-765. [CrossRef]

80. Chaffer, C.L.; Weinberg, R.A. How Does Multistep Tumorigenesis Really Proceed? Cancer Discov. 2015, 5, 22-24. [CrossRef]

81. Venkatesh, J.; Rishi, A.K.; Reddy, K.B. Novel strategies to target chemoresistant triple-negative breast cancer. Genes Cancer 2020, 1-11. Available online: https://www.genesandcancer.com/article/204/pdf/ (accessed on 10 September 2020).

82. Xu, L.; Yin, S.; Banerjee, S.; Sarkar, F.; Reddy, K.B. Enhanced anticancer effect of the combination of cisplatin and TRAIL in triple-negative breast tumor cells. Mol. Cancer Ther. 2011, 10, 550-557. [CrossRef]

83. Yang, Y.-P.; Chien, Y.; Chiou, G.-Y.; Cherng, J.-Y.; Wang, M.-L.; Lo, W.-L.; Chang, Y.-L.; Huang, P.-I.; Chen, Y.-W.; Shih, Y.-H.; et al. Inhibition of cancer stem cell-like properties and reduced chemoradioresistance of glioblastoma using microRNA145 with cationic polyurethane-short branch PEI. Biomaterials 2012, 33, 1462-1476. [CrossRef] [PubMed]

84. Yin, S.; Cheryan, V.T.; Xu, L.; Rishi, A.K.; Reddy, K.B. Myc mediates cancer stem-like cells and EMT changes in triple negative breast cancers cells. PLoS ONE 2017, 12, e0183578. [CrossRef] [PubMed]

85. Yin, S.; Xu, L.; Bandyopadhyay, S.; Sethi, S. Cisplatin and TRAIL enhance breast cancer stem cell death. Int. J. Oncol. 2011, 39, 891-898. [CrossRef] [PubMed]

86. Hoey, T.; Yen, W.-C.; Axelrod, F.; Basi, J.; Donigian, L.; Dylla, S.; Fitch-Bruhns, M.; Lazetic, S.; Park, I.-K.; Sato, A.; et al. DLL4 Blockade Inhibits Tumor Growth and Reduces Tumor-Initiating Cell Frequency. Cell Stem Cell 2009, 5, 168-177. [CrossRef]

87. Harrison, H.; Farnie, G.; Howell, S.J.; Rock, R.E.; Stylianou, S.; Brennan, K.R.; Bundred, N.J.; Clarke, R.B. Regulation of Breast Cancer Stem Cell Activity by Signaling through the Notch4 Receptor. Cancer Res. 2010, 70, 709-718. [CrossRef]

88. Kaplan, R.N.; Riba, R.D.; Zacharoulis, S.; Bramley, A.H.; Vincent, L.; Costa, C.; Macdonald, D.D.; Jin, D.K.; Shido, K.; Kerns, S.A.; et al. VEGFR1-positive haematopoietic bone marrow progenitors initiate the pre-metastatic niche. Nature 2005, 438, 820-827. [CrossRef]

89. Gordan, J.D.; Bertovrt, J.A.; Hu, C.-J.; Diehl, J.A.; Simon, M.C. HIF-2 $\alpha$ Promotes Hypoxic Cell Proliferation by Enhancing c-Myc Transcriptional Activity. Cancer Cell 2007, 11, 335-347. [CrossRef] 
90. Li, Z.; Bao, S.; Wu, Q.; Wang, H.; Eyler, C.; Sathornsumetee, S.; Shi, Q.; Cao, Y.; Lathia, J.; McLendon, R.E.; et al. Hypoxia-Inducible Factors Regulate Tumorigenic Capacity of Glioma Stem Cells. Cancer Cell 2009, 15, 501-513. [CrossRef]

91. Takahashi, K.; Yamanaka, S. Induction of Pluripotent Stem Cells from Mouse Embryonic and Adult Fibroblast Cultures by Defined Factors. Cell 2006, 126, 663-676. [CrossRef] [PubMed]

92. Kang, L.; Mao, J.; Tao, Y.; Song, B.; Ma, W.; Lu, Y.; Zhao, L.; Li, J.; Yang, B.; Li, L. MicroRNA-34a suppresses the breast cancer stem cell-like characteristics by downregulating Notch1 pathway. Cancer Sci. 2015, 106, 700-708. [CrossRef] [PubMed]

93. Liu, C.; Kelnar, K.; Liu, B.; Chen, X.; Calhoun-Davis, T.; Li, H.; Patrawala, L.; Yan, H.; Jeter, C.R.; Honorio, S.; et al. The microRNA miR-34a inhibits prostate cancer stem cells and metastasis by directly repressing CD44. Nat. Med. 2011, 17, 211-215. [CrossRef] [PubMed]

94. Cheng, W.; Liu, T.; Wan, X.; Gao, Y.; Wang, H. MicroRNA-199a targets CD44 to suppress the tumorigenicity and multidrug resistance of ovarian cancer-initiating cells. FEBS J. 2012, 279, 2047-2059. [CrossRef]

Publisher's Note: MDPI stays neutral with regard to jurisdictional claims in published maps and institutional affiliations.

(C) 2020 by the author. Licensee MDPI, Basel, Switzerland. This article is an open access article distributed under the terms and conditions of the Creative Commons Attribution (CC BY) license (http://creativecommons.org/licenses/by/4.0/). 